reviewed, to see whether there are not any gaps to be filled in it; some men of science, for example, consider that the existing Research Councils (including, of course, the Department for Scientific and Industrial Research) might profitably be supplemented by the creation of a Biological Research Couneil, which, in addition to covering a wide field of research which is not at present adequately covered by the existing Councils, could take over under unified control some of the biological projects now dispersed among the others.

To return to the international sphere, it is of great importance that men of science should realize the need for 'high-level' representation of science in the United Nations Organisation, in direct relation to the three Councils. This is all the more urgent since not only is such a function of science in no way covered by the United Nations Educational and Cultural Organisation, still less by the other special agencies, but it has not yet been envisaged by the Preparatory Commission of the United Nations Organisation (see the recently published Report of its Executive Committee) - in spite of the fact that the first session of the General Assembly of the United Nations is to meet in London in January.

\section{WORLD CO-OPERATION IN SCIENCE}

\section{By J. G. CROWTHER}

$\mathrm{T}$ HE present Conference and proposals for educational, scientific and cultural co-operation have arisen, in the first instance, through the devastation of war. When countries were invaded, millions of men and women retreated before the enemy, and hundreds of thousands came to the United Kingdom. The children and the young needed succour and education, and through this, the Ministers of Education of the occupied countries met to organize assistance. From immediate help for refugees, they passed to plans for assisting the cultural life of their countries after liberation, and then to the promotion of cultural co-operation on a new world scale. There were the three stages of relief, rehabilitation, and the advancement of civilization.

Each of these stages has its special problems. In the educational field, books and elementary teaching equipment are the most important mass need. The urgency of the provision of text-books, pencils, desks, paper, and the other elementary things is extreme. In principle, it does not seem to be a very difficult problem. The great difficulties that arise in practice are shortage of raw materials, labour, machinery and the organization of production. Their solution would be straightforward, if economic conditions were easy.

In the field of rehabilitation concerned with more advanced institutions, the problems are much less clear. How should a restored physics research laboratory be equipped ? Should its old equipment be looked for, and put back; or should modern up-to-date equipment be installed? Should the balance of selection of new equipment be the same as the old ?

It is evident that rehabilitation of advanced and university laboratories is a complex and highly technical job. A pooling of world information on equip- ment and a pooling of world opinion on methods of equipping scientific institutions are required.

The Conference of Allied Ministers of Education, which gave rise to the present Conference, has already done a considerable amount of work on the compilation of inventories of equipment for a wide range of teaching and academic laboratories. The various inventories for chemical, physical, agricultural, medical and engineering laboratories have been compiled by committees of men of science of various nationalities.

It is possible that their labours contain the germ of the rationalization of scientific equipment. The new organization should extend this work.

A second needed activity is the survey of the world needs of scientific equipment. In the process of its work, the Science Commission of the Conference of Allied Ministers of Education had occasion to estimate the value of scientific equipment that existed in nine occupied European countries. They found that it was of the order of $£ 100,000,000$. There is a striking lack of economic data of this kind. No one ever seems to have asked before exactly what the world needs of scientific equipment might be. It is evident that such data are essential for the planning of the massproduction of scientific equipment at low prices. For example, steam-engines of various kinds are needed for engineering laboratories. Their price varies greatly according to whether they are needed in lots of five or five hundred. The cost of scientific rehabilitation could be greatly reduced if the world manufacture of scientific equipment could be to some extent rationalized.

The world Organisation could promote similar action with regard to scientific and engineering textbooks. For example, a uniform system of units might be introduced. A common denominator for the decimal and the foot-pound systems would enable men of science and engineers to refer to books in any language, without the confusion of incommensurable sizes and units.

Another direction in which there is need for positive innovation is in the types of research fellow. ship. Something in the nature of 'research visitors' should be invented. There is a great need for the provision of small sums to enable research workers to make short visits for periods of a week to three months, to demonstrate or learn a new technique, or to travel to a laboratory where there is unique apparatus, in order to make a special experiment. There is very much less resource for this kind of journey than for studentships and fellowships of one year's minimum duration. The promotion of contact between men of science should be much more flexible and varied. The new Organisation should compare what various countries are doing in this way, make a list of world resources for means for travel, and direct the attention of particularly good systems that exist in one country to the notice of others.

There is general agreement that the small scientific conference of specialists should be encouraged. Allied to this development is the provision of accommodation for scientific workers and men of learning travelling about the world. A chain of houses in the leading cities and centres of the world should be developed, so that a man of science going from one country to another can be sure of a comfortable, informed and inexpensive reception everywhere. A pooling of the ideas of the nations on this topic might lead to interesting innovations.

Yet another direction for development is in the 
encouragement of new contacts between different branches of science. An efficient world Organisation would have unequalled opportunities for bringing together fertile new personalities and ideas, lying outside the old classifications and organizations. The most obvious ground for development is in the region between the natural and the social sciences.

While new subjects should be stimulated and fertilized, similar attention should be paid to now places. Modern means of transport and communication have brought eities hitherto quite isolated from the cultural current of the world within a few hours' journey of the main centres. A few years ago, the acceptance of a scientific post in an institute in a distant country usually meant cultural exile. With a world Organisation to assist in communications, such an outpost may offer more interesting opportunities to the research worker than he may find in the more crowded and conventional places at home.

A world Organisation for educational, scientific and cultural co-operation, conducted with a positive constructive spirit, ean perform great and necessary services in the extension of existing international scientific co-operation, and the creation of new activities to meet the needs of the times.

\section{A PERMANENT INTERNATIONAL SCIENTIFIC COMMISSION}

\section{By Prof. J. D. BERNAL, F.R.S. Birkbeck College}

$I^{\mathrm{T}}$

$T$ is sincerely to be hoped that the United Nations Conference for the Establishment of an Educational and Cultural Organisation will, as one result of its deliberations, set up some form of international scientific commission. Such a body has long been needed and never more than in the present period of rehabilitation and reconstruction. The experiences of the War have shown, not only in industrial countries but also in the agricultural and other undeveloped regions, that the rational application of scientific knowledge and the initiation and carrying out of research and development in relation to current problems is an absolute necessity for progress. The War has also shown that the gap which has long existed between scientific research and practical results can, with suitable organization, be drastically narrowed. This experience bears with it the responsibility for seeing that methods at least as efficient shall be put into operation with the minimum of delay for the purposes of peace.

One of the main lessons of war science was its transcendence of national boundaries. In most fields of science there was a complete pooling of British Commonwealth and United States of America scientific resources. In some fields of science, notably medical, the pooling also included, within limits of difficulties of communication, the Soviet Union and China. But the actual geographical extent of scientific collaboration was still wider; it ranged over the whole of the fields of operation of allied armies and supply services, that is, over practically all but enemy-occupied territory. The work was planned and co-ordinated in regard to problems and needs rather than to individual and national contributions. The British Commonwealth Scientific Office in Washington was a focus of common scientific planning and information such as has never existed in the world before and one well justified by its results. There could be correlated, for example, work on insecticides such as D.D.T. being applied all the way from New Guinea to West Africa, and this was not the only centre. Men of science attached to the Middle East Supply Centre at Cairo were examining all the related problems of the region---of agriculture, industry and health-from Moroce to Baluchistan. The advantages to be got from seientific collaboration on a regional basis are now proved; but to safeguard them requires a permanent form of organization which only the United Nations can provide.

Another lesson of equal importance was that the distinction between the different sciences tended to disappear in practice in this type of organization. In fact one of the main lessons of the War was that mixed research teams, ranging from mathematicians and physicists to economists and psychologists, were needed to cope with regional problems in their entirety. Even in highly industrialized countries we are beginning to find out that the physical scientists and the technicians cannot get to work effectively unless they can see their problems in a framework which only social scientists ean grasp and which only statisticians can convert into figures on which quantitative action can be taken. This was effectively what was done in the building up of "operationa] research" during the War, and already the techniques of operational research are being applied to the building and export industries in Britain. The need for them on an international scale will be far greater.

The world of science after the War is ripe for great changes. In the United States and Great Britain science has been relatively undamaged and much increased in scope and effective organization. In the Soviet Union, in spite of the almost total devastation of the western areas, science has not only been maintained but has grown. By contrast, in the majority of the occupied countries, science has barely survived destruction and persecution, while both there and in the countries of Asia and Africa there is an increasingly conscious demand for more science. The devastated countries noed immediate help, but it will not be sufficient, or, indeed, desirable, simply to return to pre-war conditions. The smaller countries already feel the need for larger units of scientific intercommunication. In a sense, German science provided this before the War, and the filling of the vacuum left by the perversion and destruction of German science is a task which can only be carried out by organized international action. It should be possible to get away from the conception which had grown up before the War, of scientific circles confined to a large extent by the eirculation of journals in the same language, towards one of a world scientific commonwealth. This implies, however, a serious effort to recast the whole system of scientific publication and personal communication.

Such a task is eminently one for the new United Nations Organisation. What is a reconstitution of science in some of the European countries is, for many of the backward countries of the world, a first creation of science. The history of the Soviet Republies of Central Asia shows how rapidly science can be built up and how eagerly it is seized on by a population starting from a medieval standard of culture. During the war years we have seen another example in the extraordinary effort to expand and apply science which has been carried out under the most adverse conditions in China. The part that Dr. Joseph Needham's Sino-British Mission has taken in 